\title{
Racial inequalities in the socioeconomic, demographic and health conditions of elderly from Maranhão State, Legal Amazon, Brazil: a population-based study
}

\author{
Bruno Luciano Carneiro Alves de OLIVEIRA ${ }^{1 *}$, Alécia Maria da SILVA², Raimundo Antonio da SILVA², \\ Erika Barbara Abreu Fonseca THOMAZ ${ }^{1}$ \\ 1 Universidade Federal do Maranhão (UFMA). Graduate Program in Collective Health. Rua Barão de Itapary NNo 155, Centro, CEP: 65.020-070, São Luís, MA, Brazil. \\ 2 Municipal Department of Health, Cururupu, MA, Brazil. E-mail: aleciamsilva@gmail.com \\ * Corresponding author: brunodeoliveirama@gmail.com
}

\begin{abstract}
Aging with quality of life does not occur equally among the racial groups of Brazilian elderly, and few studies have analyzed this issue in the states of the Brazilian Legal Amazon. The objective of this study was to investigate racial inequalities in the socioeconomic, demographic and health conditions of elderly residents of Maranhão state, Brazil. The present work is a crosssectional study of 450 elders aged 60 years or older included in the 2008 National Household Sample Survey. The prevalence of socioeconomic, demographic, health and habit indicators and of risk factors were estimated in white, brown and black racial categories that were self-reported by the survey participants. The chi-square test was used for comparisons $(\alpha=5 \%)$. The majority of the elderly respondents identified themselves as brown $(66.4 \%)$ or white $(23.3 \%)$. There were significant socioeconomic, demographic, habit and lifestyle differences among the racial groups. Most of the black and brown elderly lived alone, reported lower educational levels and were in the lowest quintile for income. These respondents were also highly dependent on the Unified Health System (Sistema Único de Saúde - SUS), exhibited low rates of screening mammograms and lower physical activity levels and had a greater proportion of smokers. However, there was no difference in the prevalence of health indicators or in the proportion of elderly by gender, age, social role in the family or the urban-rural location of the household. These results indicate the presence of racial inequalities in the socioeconomic and demographic status and in the practice of healthy habits and lifestyles among elderly from Maranhão, but suggest equity in health status. The results also suggest the complexity and challenges of interlinking race with socioeconomic aspects, and the findings reinforce the need for the implementation of public policies for these population groups.
\end{abstract}

KEYWORDS: aging, social inequity, epidemiology, indicators, race or ethnic group distribution.

\section{Desigualdades raciais na condição socioeconômica, demográfica e de saúde dos idosos do Estado do Maranhão, Amazônia Legal, Brasil: um estudo de base populacional}

\section{RESUMO}

O envelhecimento com qualidade de vida não ocorre de modo equitativo nos grupos raciais de idosos brasileiros e poucas pesquisas analisam este tema nos Estados da Amazônia Legal. O objetivo desta pesquisa foi investigar desigualdades raciais na condição socioeconômica, demográfica e de saúde de idosos maranhenses. Trata-se de estudo transversal envolvendo 450 idosos com 60 anos ou mais incluídos na Pesquisa Nacional por Amostra de Domicílios 2008. Estimaram-se prevalências para indicadores socioeconômicos, demográficos, de saúde e de hábitos e fatores de risco, segundo as categorias raciais branca, parda ou preta autorreferidas. Utilizou-se o teste Qui-quadrado nas comparaçóes $(\alpha=5 \%)$. A maioria dos idosos referiu-se como pardos $(66,4 \%)$ ou brancos $(23,3 \%)$. Observaram-se significativas diferenças socioeconômicas, demográficas e nos hábitos e estilos de vida entre os grupos raciais. Idosos pretos e pardos, em maior proporçáo, moravam sozinhos, referiram menor escolaridade e estavam no pior quintil de renda. Apresentaram, também, elevada dependência do Sistema Único de Saúde, baixa realização de mamografia, menor prática de atividade física e maior proporção de fumantes. Contudo, não houve diferença nas prevalências dos indicadores de saúde nem na proporção de idosos segundo o gênero, faixa etária, papel social na família e localização urbano-rural do domicílio. Estes resultados indicam a presença de desigualdades raciais na condição socioeconômica, demográfica, na adesão a hábitos e estilos de vida saudáveis, mas sugerem equidade em saúde. Apontam a complexidade e os desafios do entrecruzamento da raça com aspectos socioeconômicos e reforçam a necessidade da implementação de políticas públicas voltadas para estes grupos populacionais.

PALAVRAS-CHAVE: envelhecimento, iniquidades sociais, epidemiologia, indicadores, distribuição por raça ou etnia. 


\section{INTRODUCTION}

Population aging with quality of life is one of the great challenges of contemporary public health because it does not occur in a fair and homogeneous way in the different subgroups of elderly (Jardim et al. 2006; Alencar et al. 2010). In Brazil, the proportion of elderly population is increasing in an intensive and accelerated way in all regions and states of the Federation, but this population is still characterized by the unequal distribution of risk and protective factors and health problems among the racial groups of elderly residents in these areas (Rebouças et al. 2011; Oliveira 2013).

Studies reveal that elderly black and brown Brazilians exhibit worse general living conditions and health status compared to the elderly white population (Rebouças e Pereira 2008; Oliveira 2013). These racial inequalities would be generated throughout the various life stages until old age through complex interactive mechanisms of color/race with markers of social status, which would be expressed in the individual and contextual indicators that are widely used to assess and monitor the social and health profiles of the elderly (Rebouças e Pereira 2008; Oliveira 2013).

However, there is currently little information on racial inequalities during the aging of residents of the states that compose the Brazilian Legal Amazon, thus limiting the determination of the local situation of racial groups of elderly in this important macro-region (Araújo et al. 2010; Rebouças et al. 2011; IBGE 2011a).

This evaluation is particularly important in Maranhão state, Brazil, because this state has the largest number and percentage of elderly residents in the Brazilian Legal Amazon. In 2010, this state had 568,681 elderly people, which represented $8.6 \%$ of its general population and $30.1 \%$ of the elderly in the Brazilian Legal Amazon. Additionally, Maranhão is the Brazilian state with the third highest proportion of African descents, is the second poorest state in the Federation and is still in the intermediate stage of demographic and epidemiological transition (IBGE 2011a; PNUD 2013). Therefore, it is hypothesized that striking racial inequalities occur in the socioeconomic, demographic and health conditions among the elderly in this Brazilian state.

Although previous studies have already indicated serious social inequalities in the general living condition in Maranhão state (IBGE 2010; Oliveira et al. 2010), few studies have evaluated the presence of racial inequalities and their current impacts on racial composition and socioeconomic, demographic and health conditions in elderly residents of Maranhâo state (Oliveira et al. 2010; Oliveira 2013). Thus, the racial gradients in the general living conditions and health status of the elderly living in part of the Brazilian Legal Amazon are still unknown. The aim of this study was to investigate the presence of racial inequalities in the socioeconomic, demographic and health conditions of elderly residents of Maranhão state, Brazil.

\section{MATERIALS AND METHODS}

The study has a cross-sectional design, and the National Household Sample Survey (Pesquisa Nacional por Amostra de Domicílios - PNAD), conducted in 2008 by the Brazilian Institute of Geography and Statistics (Instituto Brasileiro de Geografia e Estatística - IBGE), was used as the data source. The PNAD is a population-based survey that is conducted annually. Each year, information representative of the Brazilian population is collected. In 2008, a health supplement was added, and informations about the living conditions and health status of Brazilians were obtained. The PNAD uses a complex probability sample of households from all Brazilian regions obtained during up to three selection stages (IBGE 2008).

Only municipalities of Maranhão state were included in the present study. The municipalities were selected in the first stage of the sampling. The census sectors were selected in the second stage, and finally, households were sampled in each census sector in the last stage (IBGE 2008). A total of 7,287 individuals from 1,841 households of Maranhão state were surveyed. Of these individuals, 630 individuals were 60 years or older. Elderly whose information about color/race was reported by others $(\mathrm{n}=173)$ and elderly belonging to the yellow $(\mathrm{n}=05)$ or indigenous $(\mathrm{n}=01)$ color/race categories or with a non-reported category $(\mathrm{n}=01)$ were excluded from the study. Thus, the final population analyzed in this study consisted of 450 elderly, who identified themselves as white, brown or black (IBGE 2008). Thus, the IBGE criterion that recommends the use of self-reported color/race in health studies was adopted (Travassos and Williams 2004; IBGE 2011a).

In the PNAD, the classification of color or race is synonymous. The interviewees are encouraged to represent their race when referring to their skin color. Thus, the question about color/race reveals the racial group with which the individuals identify themselves (Travassos and Williams 2004; IBGE 2011a). However, in Brazil, this pattern of racial classification combines phenotypic and socioeconomic aspects. Depending on the individual or contextual features, the formed racial groups might not be homogeneous, and individuals do not always belong to the groups in a definite and unequivocal manner (Travassos and Williams 2004; Maio et al. 2005).

In this study, demographic, socioeconomic, health and habit indicators and risk factors were used, taking as a reference a matrix of indicators widely used to assess the living conditions and health status of Brazilian elderly (Rebouças e Pereira 2008; Rebouças et al. 2011). The following 
demographic indicators comprised this study: gender (male or female), age (in completed years grouped into three age groups: $60-69,70-79$ and $\geq 80$ years); role in the family (grouped into three categories: head of household, spouse and others); number of household members (grouped into three categories: 1,2 and $\geq 3$ persons); location of the residence (urban or rural).

The following socioeconomic indicators were considered: educational level (years of schooling grouped into three levels: 0, 1-8 and $\geq 9$ years); economic activity status (active or inactive); quintile of the per capita household income (grouped in five quintiles: $1^{\text {st }}$ [lowest], $2^{\text {nd }}, 3^{\text {rd }}, 4^{\text {th }}$ and $5^{\text {th }}$ [highest]), where the median income in the $1^{\text {st }}$ quintile was $\mathrm{R} \$$ 114.50 , and the income in the $5^{\text {th }}$ quintile was $R \$ 1,241.50$. The minimum wage in 2008 was $\mathrm{R} \$ 415.00$ (approximately US\$226.65).

The following health indicators were considered: selfassessment of general health status (grouped into five response categories: very good, good, fair, poor and very poor); functional disability (grouped into three categories: none, small and moderate); and number of chronic diseases and conditions (grouped into three categories: 0,1 and $\geq 2$ ). The number of chronic diseases and conditions was obtained by the sum of all the diseases investigated in the PNAD.

The following habit indicators and risk factors were considered: having private health insurance (yes or no); screening mammograms (grouped into four categories: less than 1 year, 1-3 years, over 3 years and never had it); cervical cancer prevention (grouped into three categories: up to 1 year, over 1 year and never had it); physical activity practice in commuting to work or leisure (yes or no) and current smoking habit (yes or no).

The qualitative variables were expressed as absolute and percentage frequencies. The prevalence and the respective 95\% confidence interval $(95 \% \mathrm{CI})$ of the study variables according to race/color categories were estimated. To compare the frequencies of the indicators among racial groups, the chi-square test with the Rao-Scott approximation was used. A significance level of 5\% was adopted. The Rao-Scott test corrects the chi-square test for a complex sample design. All of the analyses were performed in the Stata software version 10.0 (Stata Corp., College Station, Texas, EUA)', incorporating the complex design effect (deff) (Silva et al. 2002) of the PNAD 2008 through the svy procedures.

\section{RESULTS}

This study included a sample of 450 elderly from Maranháo state, of which 66.4\% (95\% CI: 61.9-70.7) declared themselves as brown, $23.3 \%$ (95\% CI: 19.6-27.5) as white, and $10.3 \%$ (95\% CI: 7.7-13.4) as black. The median age was 68 years (64-74). According to the table 1, elderly women in the age group of 60-69 years, who represented the head of household and who lived in urban areas were more prevalent in the three racial groups but without significant differences among the groups. However, the number of household members differed among the racial groups $(p=0.005)$. The proportion of the black elderly who lived alone was three times higher than in the other racial groups. Most of the brown and white elderly lived in households with three or more people.

The brown and black elderly exhibited lower educational levels than the white elderly $(p \leq 0.0001)$. The proportion of white elderly with nine or more years of schooling was twofold higher than that of the black elderly. The proportion of brown and black elderly in the worst quintile of per capita household income was higher than that of the white elderly $(p=0.0002)$. The proportion of white elderly in the best quintile of household income was almost fivefold higher than that observed for the brown elderly (Table 2).

There were no significant differences among the health indicators according to the racial categories evaluated. However, the black elderly displayed a higher proportion of individuals self-assessing their health status as very poor and their functional disability as small; the brown elderly exhibited more chronic diseases or conditions (Table 3).

The proportion of individuals that had private health insurance was significantly different among the racial groups $(p \leq 0.0001)$. The brown and black elderly depended almost exclusively on the Unified Health System (Sistema Único de Saúde - SUS). The majority of the brown and black elderly women had never had a mammography, which was different from the pattern observed among the white elderly women $(p \leq 0.01)$. Physical inactivity and a lack of smoking habit were common in all three of the groups, but the white elderly practiced more physical activity $(p=0.04)$ and smoked less than the black and brown elderly $(p=0.05)$ (Table 4$)$. 
Table 1. Demographic indicators of elderly residents of Maranhão state aged 60 years or older $(n=450)$ who self-reported their race/color, PNAD 2008.

\begin{tabular}{|c|c|c|c|c|c|c|c|}
\hline \multirow[t]{2}{*}{ Indicators } & \multicolumn{2}{|c|}{$\begin{array}{c}\text { White } \\
(n=105)\end{array}$} & \multicolumn{2}{|c|}{$\begin{array}{l}\text { Brown } \\
(n=299)\end{array}$} & \multicolumn{2}{|c|}{$\begin{array}{c}\text { Black } \\
(n=46)\end{array}$} & \multirow[t]{2}{*}{$\mathrm{p}$-valor ${ }^{\mathrm{a}}$} \\
\hline & $\%$ & $(95 \% \mathrm{Cl})$ & $\%$ & $(95 \% \mathrm{Cl})$ & $\%$ & $(95 \% \mathrm{Cl})$ & \\
\hline \multicolumn{7}{|l|}{ Gender } & \multirow{3}{*}{0.35} \\
\hline Male & 37.1 & $(28.4-46.8)$ & 45.2 & $(39.6-50.9)$ & 45.7 & $(31.9-60.1)$ & \\
\hline Female & 62.9 & $(53.2-71.6)$ & 54.8 & $(49.2-60.4)$ & 54.3 & $(39.9-68.1)$ & \\
\hline \multicolumn{7}{|l|}{ Age group (years) } & \multirow{4}{*}{0.78} \\
\hline $60-69$ & 53.3 & $(43.8-62.7)$ & 57.5 & $(51.8-63.0)$ & 56.5 & $(42.0-70.0)$ & \\
\hline $70-79$ & 38.1 & $(29.3-47.8)$ & 32.5 & $(27.4-38.0)$ & 30.5 & $(18.9-45.1)$ & \\
\hline$\geq 80$ & 8.6 & $(4.5-15.7)$ & 10.0 & $(7.1-14.0)$ & 13.0 & $(6.0-26.2)$ & \\
\hline \multicolumn{7}{|l|}{ Role in the family } & \multirow{4}{*}{0.81} \\
\hline Head of household & 66.6 & $(57.1-75.0)$ & 70.9 & (65.5-75.8) & 76.1 & $(61.7-86.3)$ & \\
\hline Spouse & 24.8 & $(17.4-33.9)$ & 22.4 & $(18.0-27.5)$ & 17.4 & $(8.9-31.2)$ & \\
\hline Other & 8.6 & $(4.5-15.7)$ & 6.7 & $(4.4-10.2)$ & 6.5 & $(2.1-18.4)$ & \\
\hline \multicolumn{7}{|c|}{ Number of household members } & \multirow{4}{*}{0.005} \\
\hline 1 & 10.5 & $(5.9-18.0)$ & 11.4 & $(8.2-15.5)$ & 30.4 & $(18.9-45.1)$ & \\
\hline 2 & 25.7 & $(18.2-34.9)$ & 20.4 & $(16.2-25.4)$ & 19.6 & $(10.5-33.6)$ & \\
\hline$\geq 3$ & 63.8 & $(54.2-72.4)$ & 68.2 & $(62.7-73.3)$ & 50.0 & $(35.9-64.1)$ & \\
\hline \multicolumn{7}{|l|}{ Location of the residence } & \multirow{3}{*}{0.96} \\
\hline Urban & 64.8 & $(55.2-73.3)$ & 63.5 & $(57.9-68.8)$ & 65.2 & $(50.5-77.5)$ & \\
\hline Rural & 35.2 & $(26.7-44.9)$ & 36.5 & $(31.2-42.1)$ & 34.8 & $(22.5-49.5)$ & \\
\hline
\end{tabular}

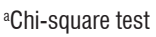

Table 2. Socioeconomic indicators of elderly residents of Maranhão state aged 60 years or older $(n=450)$ who self-reported their race/color, PNAD 2008.

\begin{tabular}{|c|c|c|c|c|c|c|c|}
\hline \multirow{2}{*}{ Indicators } & \multicolumn{2}{|c|}{$\begin{array}{c}\text { White } \\
(n=105)\end{array}$} & \multicolumn{2}{|c|}{$\begin{array}{l}\text { Brown } \\
(n=299)\end{array}$} & \multicolumn{2}{|c|}{$\begin{array}{c}\text { Black } \\
(n=46)\end{array}$} & \multirow{2}{*}{$p$-valor ${ }^{\mathrm{a}}$} \\
\hline & $\%$ & $(95 \% \mathrm{Cl})$ & $\%$ & $(95 \% \mathrm{Cl})$ & $\%$ & $(95 \% \mathrm{Cl})$ & \\
\hline \multicolumn{7}{|l|}{ Educational level (years) } & \multirow{4}{*}{0.0001} \\
\hline 0 & 44.8 & $(35.5-54.4)$ & 62.9 & $(57.2-68.2)$ & 65.2 & $(50.5-77.5)$ & \\
\hline $1-8$ & 35.2 & $(26.7-44.9)$ & 34.1 & $(28.9-39.7)$ & 23.9 & $(13.7-38.3)$ & \\
\hline$\geq 9$ & 20.0 & $(13.4-28.8)$ & 3.0 & $(1.6-5.7)$ & 10.9 & $(4.6-23.7)$ & \\
\hline \multicolumn{7}{|l|}{ Economic activity } & \multirow{3}{*}{0.91} \\
\hline Active & 33.3 & $(25.0-42.9)$ & 34.4 & $(29.3-40.0)$ & 37.0 & $(24.3-51.7)$ & \\
\hline Inactive & 66.7 & $(57.1-75.0)$ & 65.6 & $(60.0-70.7)$ & 63.0 & $(48.3-75.7)$ & \\
\hline \multicolumn{7}{|c|}{ Quintile of the household income ${ }^{b}$} & \multirow{6}{*}{0.0002} \\
\hline 1st $(\mathrm{R} \$ 114.50)$ & 8.7 & $(4.6-15.8)$ & 13.8 & $(10.3-18.2)$ & 13.0 & $(6.0-26.2)$ & \\
\hline 2nd & 22.1 & $(15.1-31.1)$ & 22.9 & $(18.5-28.0)$ & 13.0 & $(6.0-26.2)$ & \\
\hline $3 r d$ & 31.7 & $(23.5-41.3)$ & 46.1 & $(40.5-51.8)$ & 52.2 & $(37.9-66.1)$ & \\
\hline 4th & 19.2 & $(12.7-28.0)$ & 13.1 & $(9.7-17.5)$ & 10.9 & $(4.6-23.6)$ & \\
\hline 5th $(\mathrm{R} \$ 1,241.50)$ & 18.3 & $(11.9-26.9)$ & 4.1 & $(2.3-7.0)$ & 10.9 & $(4.6-24.0)$ & \\
\hline
\end{tabular}

aChi-square test; ${ }^{\circ}$ For the quintile of the household income, 104 white and 297 brown respondents were analyzed. 
Table 3. Health indicators of elderly residents of Maranhão state aged 60 years or older $(n=450)$ who self-reported their race/color, PNAD 2008.

\begin{tabular}{|c|c|c|c|c|c|c|c|}
\hline \multirow{2}{*}{ Indicators } & \multicolumn{2}{|c|}{$\begin{array}{l}\text { White } \\
(n=105)\end{array}$} & \multicolumn{2}{|c|}{$\begin{array}{l}\text { Brown } \\
(\mathrm{n}=299)\end{array}$} & \multicolumn{2}{|c|}{$\begin{array}{c}\text { Black } \\
(n=46)\end{array}$} & \multirow{2}{*}{$\mathrm{p}$-valor ${ }^{\mathrm{a}}$} \\
\hline & $\%$ & $(95 \% \mathrm{Cl})$ & $\%$ & $(95 \% \mathrm{Cl})$ & $\%$ & $(95 \% \mathrm{Cl})$ & \\
\hline \multicolumn{7}{|c|}{$\begin{array}{l}\text { Self-assessment of the health } \\
\text { status }\end{array}$} & \multirow{6}{*}{0.23} \\
\hline Very good & 4.8 & $(2.0-11.0)$ & 2.3 & $(1.1-4.8)$ & 4.3 & $(1.1-15.9)$ & \\
\hline Good & 30.4 & (22.4-39.9) & 30.8 & $(25.8-36.2)$ & 43.5 & $(30.0-58.0)$ & \\
\hline Fair & 42.9 & $(33.7-52.5)$ & 44.8 & $(39.2-50.5)$ & 34.8 & $(22.5-49.5)$ & \\
\hline Poor & 20.0 & $(13.4-28.8)$ & 16.7 & $(12.9-21.4)$ & 8.7 & $(3.3-21.0)$ & \\
\hline Very poor & 1.9 & $(0.5-7.3)$ & 5.4 & $(3.3-8.6)$ & 8.7 & $(3.3-21.0)$ & \\
\hline \multicolumn{7}{|c|}{ Number of chronic conditions } & \multirow{4}{*}{0.32} \\
\hline 0 & 36.2 & (27.6-45.8) & 35.8 & $(30.5-41.4)$ & 36.9 & $(24.3-51.7)$ & \\
\hline 1 & 28.6 & $(20.7-38.0)$ & 37.1 & $(31.8-42.8)$ & 41.4 & $(28.1-55.9)$ & \\
\hline$\geq 2$ & 35.2 & $(26.7-44.9)$ & 27.1 & $(22.3-32.4)$ & 21.7 & $(12.1-36.0)$ & \\
\hline \multicolumn{7}{|c|}{ Functional disability } & \multirow{4}{*}{0.45} \\
\hline None & 80.0 & $(71.2-86.6)$ & 82.6 & $(77.9-86.5)$ & 78.3 & $(64.1-87.9)$ & \\
\hline Small & 12.4 & (7.3-20.2) & 12.0 & $(8.8-16.3)$ & 19.5 & $(10.5-33.6)$ & \\
\hline Moderate & 7.6 & $(3.9-14.5)$ & 5.4 & $(3.3-8.6)$ & 2.2 & $(0.3-14.0)$ & \\
\hline
\end{tabular}

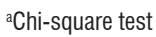

Table 4. Life-habit indicators and risk factors of elderly residents of Maranhão state aged 60 years or older $(n=450)$ who self-reported their race/color, PNAD 2008.

\begin{tabular}{|c|c|c|c|c|c|c|c|}
\hline \multirow[t]{2}{*}{ Indicators } & \multicolumn{2}{|c|}{$\begin{array}{c}\text { White } \\
(n=105)\end{array}$} & \multicolumn{2}{|c|}{$\begin{array}{l}\text { Brown } \\
(n=299)\end{array}$} & \multicolumn{2}{|c|}{$\begin{array}{l}\text { Black } \\
(\mathrm{n}=46)\end{array}$} & \multirow[t]{2}{*}{$\mathrm{p}$-valor } \\
\hline & $\%$ & $(95 \% \mathrm{Cl})$ & $\%$ & $(95 \% \mathrm{Cl})$ & $\%$ & $(95 \% \mathrm{Cl})$ & \\
\hline \multicolumn{7}{|c|}{ Have health insurance } & \multirow{3}{*}{0.0001} \\
\hline No & 83.8 & $(75.4-89.7)$ & 96.7 & $(93.9-98.2)$ & 97.8 & $(86.0-99.7)$ & \\
\hline Yes & 16.2 & $(10.3-24.6)$ & 3.3 & $(1.8-6.1)$ & 2.2 & $(0.3-14.0)$ & \\
\hline \multicolumn{8}{|l|}{ Mammography ${ }^{b}$} \\
\hline Less than 1 year & 21.2 & $(12.9-32.8)$ & 11.0 & $(7.0-16.8)$ & 16.0 & $(6.1-35.9)$ & \multirow{4}{*}{0.01} \\
\hline 1 to 3 years & 25.8 & $(16.6-37.7)$ & 14.6 & $(10.0-20.9)$ & 4.0 & $(0.6-23.8)$ & \\
\hline Over 3 years & 10.6 & $(5.1-20.7)$ & 14.6 & $(10.0-20.9)$ & 4.0 & $(0.6-23.8)$ & \\
\hline Never had it & 42.4 & $(31.1-54.6)$ & 59.8 & $(52.0-67.0)$ & 76.0 & $(55.7-88.9)$ & \\
\hline \multicolumn{7}{|c|}{ Cervical cancer prevention ${ }^{b}$} & \multirow{4}{*}{0.28} \\
\hline Up to 1 year & 30.3 & $(20.4-42.5)$ & 22.0 & $(16.2-29.0)$ & 16.0 & $(6.1-35.8)$ & \\
\hline Over 1 year & 47.0 & $(35.2-59.0)$ & 45.1 & $(37.6-52.8)$ & 40.0 & $(23.0-59.9)$ & \\
\hline Never had it & 22.7 & $(14.1-34.4)$ & 32.9 & $(26.1-40.5)$ & 44.0 & $(26.2-63.5)$ & \\
\hline \multicolumn{7}{|c|}{$\begin{array}{l}\text { Practice of physical activity in } \\
\text { commuting to work or leisure }\end{array}$} & \multirow{3}{*}{0.04} \\
\hline Yes & 14.9 & $(7.3-20.2)$ & 6.4 & $(3.3-8.8)$ & 5.1 & $(1.1-15.7)$ & \\
\hline No & 85.1 & $(71.2-86.6)$ & 93.6 & (89.9-99.2) & 94.9 & $(87.1-99.7)$ & \\
\hline \multicolumn{8}{|c|}{ Current smoking habit } \\
\hline Yes & 9.5 & $(5.0-17.3)$ & 17.5 & $(13.3-22.8)$ & 25.0 & $(14.0-40.6)$ & \multirow{2}{*}{0.05} \\
\hline No & 90.5 & $(82.7-95.0)$ & 82.5 & $(77.2-86.7)$ & 75.0 & $(59.4-86.0)$ & \\
\hline
\end{tabular}

${ }^{a}$ Chi-square test; ${ }^{\circ}$ The denominator of these indicators included the total number of women $(n=255)$. 


\section{DISCUSSION}

These results suggest significant and unfair racial inequalities in the socioeconomic and demographic conditions and the health habits of elderly aged 60 years or older from the Brazilian state of Maranhão in 2008. The general living conditions and health status of the elderly analyzed in this study (born between 1914 and 1948) exhibited differences in the distribution of risk and protective factors. The brown and black elderly lived in worse socioeconomic conditions, having more dependence on public health systems, lower use of mammography service and lower adherence to healthy lifestyle practices. These racial differences may partially arise from unequal access and use of resources and social and health care services, which would indicate social rights denied throughout the various life stages until the elderly stage (Clarke and Smith 2011; Oliveira 2013).

However, the estimates of the health indicators, selfassessment of general health status, number of chronic diseases and conditions and functional disability did not vary among the racial groups. The absence of racial differences in health can be explained by the low direct effect of race on health in the context of poor socioeconomic status. This result suggests that socioeconomic inequalities might have a more significant direct effect on the health of the elderly than the inequalities generated by color/race (Campos 2009; Borim et al. 2012). However, it is likely that the variable color/race generates hierarchization and social implications, and therefore, this variable would be at the beginning of the chain of effects of socioeconomic differences (Chor 2013).

The racial composition of the elderly population of Maranhão state was different from the Brazilian elderly population included in the censuses of 2000 and 2010 (IBGE 2011b). Previous studies have reported a particular dynamic in the racial composition in Brazil, suggesting that the elderly population has become ethno-racially more diverse than observed in other countries (Clarke and Smith 2011; Oliveira 2013). However, in Maranhão state, this ethno-racial diversity is more intense but with a higher proportion of black elderly. In the present study, the proportion of black elderly was higher than that observed in the Brazilian states of Ceará, Minas Gerais, Rio de Janeiro and São Paulo (Rebouças et al. 2011), but similar to that of African descendants in Pará and Bahia, which were the Brazilian states with the highest proportion of blacks in 2010, representing almost $77.0 \%$ of the population (IBGE 2011a). Some authors consider that this pattern of racial composition in the North and Northeast regions is due to a regional project that was structured in settlement policies and a slavery-based agricultural economy (Gomes 2001; Guimarães 2004). This structure promoted a concentrated miscegenation, fusion and expressive interaction of the racial groups in these locations, especially in Maranháo state, which remains until the present day (Gomes 2001).

Significant differences in the number of household members among the three analyzed racial groups were observed. In the present study, the proportion of black elderly who lived alone was almost four times higher than that of the general population of Maranhão state surveyed in 2010 by the IBGE (IBGE 2011b), suggesting that in this state, oneperson families are more common among the elderly. Previous studies have reported an increase in the elderly population living alone but with important differences among the regions of the country (Oliveira et al. 2010; Camargos et al. 2011). A significant portion of these elderly is formed of women who are poor, with chronic diseases and low educational levels and who live in areas with poor infrastructure (Junges 2004; Camargos et al. 2011). Thus, living alone in old age can be a concern because elderly need more support, and the family is still the main provider of support in this stage of life (Camargos et al. 2011).

Regarding the distribution pattern of the socioeconomic status, the brown and black elderly still exhibited the worst educational and household income levels compared to the white elderly. These findings are similar to those observed in other studies and reveal the overlapping of brown and black elderly with the proportion of individuals who are poor and with the worst educational level (Clarke and Smith 2011; Oliveira 2013). This situation of inequality indicates that these elderly form a group that is vulnerable to risks that lead to disadvantages in lifestyles (Neri and Soares 2007; Lima-Costa et al. 2011). This pattern also suggests that the disparities in the present general living conditions originated from the denied social rights and multiple deprivations accumulated during each life stage until old age (Barros et al. 2011a; Lima-Costa et al. 2012; Oliveira 2013). Moreover, these differences can be reproduced in family members of these individuals because the income of the elderly may represent an important part of the household income (Neri and Soares 2007; Campos 2009), especially in poorer families where the elderly contribute an important fraction of the family income (Junges 2004; Neri and Soares 2007). In this study, it is likely that this condition also occurred because most of the elderly of the three evaluated racial groups reported themselves as the main breadwinner for their families.

The health indicators used on this study allow the assessment and monitoring of the health of the elderly in a more consistent manner, and these indicators are closer to the current complex concept of health (Campos 2009; LimaCosta et al. 2012). The results of the present study did not reveal racial gradients in these indicators. In Brazil, there is still no consensus about the presence of racial inequalities in the distribution of these healthcare measures. Some studies did 
not find a racial gradient (Campos 2009; Borim et al. 2012), while such a gradient was present in other studies (Campos 2009; Barros et al. 2011b; Oliveira 2013). However, questions about the role of race/color in determining health status are still common in these studies. This question is due to doubts about whether racial differences are relevant in health as an independent risk factor or are merely a consequence of the worse socioeconomic indicators exhibited by blacks compared to whites (Travassos and Williams 2004; Araújo et al. 2010). These questions remain because Brazil is a complex country, persisting as one of the higher levels of social inequalities worldwide (Araújo et al. 2010; PNUD 2013) and has a latent myth of racial democracy (Guimarães 2004; Lucena 2008). However, it is possible that health inequalities among the elderly from Maranhão state reflect broader inequalities in the society (Chor 2013). Although there were no racial differences in the health of the elderly in this study, it is believed that the variable color/race indirectly influences the health of these individuals, at least partially, by determining worse socioeconomic status for brown and black elderly (Campos 2009; Barros et al. 2011b; Borim et al. 2012).

The assessment of life-habit indicators and risk factors is essential to analyze the health status and to control risks and damages of populations (Malta et al. 2011; Rebouças et al. 2011). A set of these risk factors accounts for a large portion of the deaths from chronic degenerative diseases. Smoking, physical inactivity and inappropriate access to and use of healthcare services are included among those risk factors (Malta et al. 2011). The present study found racial differences in health-insurance coverage and rates of screening mammograms. These findings are consistent with the results of other authors (Viacava et al. 2009; Oliveira et al. 2011; Oliveira 2013). Having a health-insurance plan had different impacts among the analyzed groups. The high percentages of brown and black elderly with exclusive dependence on SUS suggest the importance of this system for reducing social inequities in health, especially for disadvantaged elderly populations (Barros et al. 2011a; Lima-Costa et al. 2012). White elderly have a highest rate of health-insurance, indicating that these individuals have a higher level of health care due to the possibilities of using both public and private services (Barros et al. 2011 a; Lima-Costa et al. 2012). Additionally, the rates of the use of mammography services by black and brown elderly women from Maranhão state in 2008 were significantly lower than the rates among the white elderly. This value was lower than the estimated rates in 2003 and 2008 for Brazilian women above 25 years of age (Oliveira et al. 2011) and the rates for women aged 50-69 years old in the city of São Luís (capital of Maranhão state) in 2003 and 2007 (Viacava et al. 2009) as well as for elderly women from the states of Minas Gerais, Rio de Janeiro and São Paulo, but the usage was higher than that of elderly women from the state of Ceará (Rebouças et al. 2011). Unlike the patterns observed in some regions of Brazil in recent years, access to mammography services was not available to all racial groups of elderly residents of Maranhão state. Although there are differences in the age groups of the women analyzed in these studies, it is possible that the recognition of the importance of mammography among the elderly women from Maranhão state is influenced by local problems related not only to access to medical services and the exam itself but also to the comprehension of the information received by these women (Viacava et al. 2009; Barros et al. 2011a). However, it should be noted that unlike in other studies, estimates of the performance of Pap smears did not differ among the racial groups surveyed but revealed high estimates of elderly women who had never had this exam in any stage of life, indicating failures in the health system in engaging women and timely diagnosing cervical cancer (Gonzaga et al. 2013).

Another important indicator assessed among the elderly residents of Maranháo state was a present smoking habit. Smoking is related to the development of several chronic diseases, and its control is the main way to reduce the occurrence of various types of tobacco-related cancers (Zaitune et al. 2012; Malta et al. 2013). Smoking is the most important risk factor for seven of the 14 main causes of death among the elderly (Zaitune et al. 2012) and increases the expenses of medical and social care in this group (Zaitune $e t$ al. 2012; Malta et al. 2013). In the present study, there was a well-defined and increasing gradient in the prevalence of smokers among the racial groups of the elderly. This habit was significantly more prevalent among the non-white elderly. This prevalence was higher than the one found in a population-based study of 1,954 elderly from four areas of São Paulo state, of which $16.8 \%$ were smokers (Zaitune et al. 2012). One possible explanation for the difference in prevalence between these surveys might be population and regional socioeconomic differences between the study sites; the smoking habit might be even more frequent among nonwhite elderly from Maranhão state because this population exhibits lower income and educational levels compared to the individuals from São Paulo State (Zaitune et al. 2012; Malta et al. 2013).

The practice of physical activity has been increasingly recognized as producing physical, psychological and social benefits (Zaitune et al. 2010; Malta et al. 2011). In the elderly, this practice helps to maintain independence, a healthier lifestyle and a higher quality of life (Zaitune et al. 2010; Malta et al. 2011). In the present study, the practice of physical activity when commuting to work or during leisure was lower than that observed in other population-based studies of elders, regardless of the racial classification (Zaitune et al. 2010). The practice of physical activity had a prevalence of 
$18.4 \%$ of the non-white elderly from four areas of Sáo Paulo state (Zaitune et al. 2010), which was significantly higher than the proportion observed in the black and brown elderly residents of Maranhão. Such differences may result from the poorer socioeconomic status, high functional dependency, absence of inclusion in economic activity and contextual features that reduce the practice of physical activity among the analyzed elderly population (Junges 2004; Zaitune et al. 2010). Therefore, actions that encourage the practice of physical activity among groups of sedentary and vulnerable individuals should be instituted.

It is worth noting some limitations of this study. The crosssectional design makes it difficult to infer the temporality in the estimates. Bias regarding prevalence and survival in the estimates based on the PNAD data might have occurred. This bias occurs because elderly with lower socioeconomic status have lower survival (Lima-Costa et al. 2012) or because institutionalized elderly (less healthy) are excluded from the PNAD sample (IBGE 2008). The use of information obtained by the administration of questionnaires may have added a memory bias to the measurement of physical activity and other variables (Zaitune et al. 2010). Moreover, there are conceptual and methodological limitations associated with the strategy of self-reporting racial categories, frequently cited to produce weak and underestimated results in studies with racial topics (Maio et al. 2005; Lucena 2008).

However, the results of this study were obtained from a population-based probability sample of elderly residents of Maranhão state, with good accuracy for local and national populations (Lima-Costa et al. 2011). The estimates are representative of the elderly population of the Brazilian Legal Amazon region because one third of the elderly of this region is in Maranhão state (IBGE 2008; IBGE 2011b). Furthermore, in this study, only the elderly who self-reported their color/race in the categories suggested by the IBGE were considered (2011b). Because racial identity may be influenced by socioeconomic, political and biological mechanisms in Brazil (Travassos and Williams 2004; IBGE 2011a), the use of self-reported color/race reduced the possibility of bias of the classification of this variable and of the prevalence of the analyzed racial groups (Travassos and Williams 2004; Maio et al. 2005).

Finally, regardless of the racial group of the elderly, population aging is an event that impacts different dimensions of human life. Thus, the achievement of health and quality of life in old age depends not only on the care provided by family members or health professionals but also on the effective participation of the whole society (Jardim et al. 2006; Alencar et al. 2010).

\section{CONCLUSION}

The results of the present study suggest the presence of significant racial inequalities in the general living conditions among the elderly residents of the Brazilian state of Maranhão. The results also indicate that the aging process in black and brown individuals occurs under conditions of overlapping risks, socioeconomic and demographic differences and lower proportions of healthy habits and lifestyles. Although racial differences in health indicators have not been observed, it is possible that the variable color/race indirectly determines the health of these elderly by inducing the risks associated with worse socioeconomic status among black elderly. Thus, the findings of this study show the complexity and challenges on interlinking race with socioeconomic aspects and reinforce the need for the implementation of public policies for these population groups, which may make fairer the current aging process that occurs in the state of Maranháo.

\section{ACKNOWLEDGEMENTS}

This study was supported by the Fundação de Amparo à Pesquisa e ao Desenvolvimento Científico e Tecnológico do Maranhão (FAPEMA), through the Edital Apoio a Artigos Científicos. Besides, the authors thank to Professor Luís Eduardo Batista for suggestions about the analysis and for reflections about racial inequalities among the elderly of Maranhão state; and to Professor Luana Giatti for the assistance in the management and use of the PNAD 2008 database.

\section{REFERENCES}

Alencar, N.A.; Aragão, J.C.B.; Ferreira, M.A.; Dantas, E.H.M. 2010. Avaliaçáo da qualidade de vida em idosas residentes em ambientes urbano e rural. Revista Brasileira de Geriatria e Gerontologia, 13:103-109.

Araújo, E.M.; Costa, M.C.N.; Hogan, V.K.; Araújo, T.M.; Batista, A.; Oliveira, L.O.A. 2010. The use of the race/color variable in public health: possibilities and limitations. Interface, 5:383-594.

Barros, M.B.A.; Francisco P.M.S.B.; Lima, M.G.; César, C.L.G. 2011a. Social inequalidades in health among the elderly. Cadernos de Saúde Pública, 27:S198-S208.

Barros, M.B.A.; Francisco, P.M.S.B.; Zanchetta, L.M.; César, C.L.G. 2011b. Tendências das desigualdades sociais e demográficas na prevalência de doenças crônicas no Brasil, PNAD: 2003-2008. Ciência e Saúde Coletiva, 16:3755-3768.

Borim, F.S.A.; Barros, M.B.A.; Neri, A.L. 2012. Autoavaliação da saúde em idosos: pesquisa de base populacional no Município de Campinas, São Paulo, Brasil. Cadernos de Saúde Pública, 28:769-780. 
Camargos M.C.S.; Rodrigues R.N.; Machado C.J. 2011. Idoso, família e domicílio: uma revisão narrativa sobre a decisão de morar sozinho. Revista Brasileira de Estudos de População, 28:217-30.

Campos, N.O.B. 2009. Os determinantes das condiçōes de saúde dos idosos do município de São Paulo em uma perspectiva de ciclo de vida. Tese de Doutorado, Universidade Federal de Minas Gerais, Belo Horizonte, Minas Gerais, Brasil. 88p.

Chor, D. 2013. Health inequalities in Brazil: race matters. Cadernos de Saúde Pública, 29:1272-1275.

Clarke, P.; Smith, J. 2011. Aging in a cultural context: cross-national differences in disability and the moderating role of personal control among older adults in the United States and England. The Journals of Gerontology Series B: Psychological Sciences and Social Sciences, 66:457-67.

Gomes, F.S. 2001. "Amostras humanas": índios, negros e relaçôes interéticas no Brasil colonial. In: Maggie Y.; Rezende C.B. (Orgs.). Raça como retórica: a construçâo da diferença. Rio de Janeiro, Civilização Brasileira, p.27-81.

Gonzaga, C.M.R.; Freitas-Junior, R.; Barbaresco, A.A.; Martins, E.; Bernardes, B.T.; Resende, A.P.M. 2013. Cervical cancer mortality trends in Brazil: 1980-2009. Cadernos de Saúde Pública, 29:599-508.

Guimarães, A.S.A. 2004. Preconceito de cor e racismo no Brasil. Revista de Antropologia, 47:9-43.

IBGE - Instituto Brasileiro de Geografia e Estatística. 2008. Pesquisa Nacional por Amostra de Domicílios. Rio de Janeiro, Instituto Brasileiro de Geografia e Estatística, 245p.

IBGE - Instituto Brasileiro de Geografia e Estatística. 2011a. Sinopse do Censo demográfico 2010. Rio de Janeiro, Instituto Brasileiro de Geografia e Estatística, 261p.

IBGE - Instituto Brasileiro de Geografia e Estatística. 2011b. Censo demográfico 2010: características da população e dos domicílios, resultados do universo. Rio de Janeiro, Instituto Brasileiro de Geografia e Estatística, 193p.

IBGE - Instituto Brasileiro de Geografia e Estatística. Coordenação de População e Indicadores Sociais. 2010. Sintese de indicadores sociais: uma análise das condiçôes de vida da população brasileira 2010. Rio de Janeiro, Instituto Brasileiro de Geografia e Estatística, 317p.

Jardim, V.C.F.S.; Medeiros, B.F.M.; Brito, A.M. 2006. Um olhar sobre o processo do envelhecimento: a percepção de idosos sobre a velhice. Revista Brasileira de Geriatria e Gerontologia, 9:25-34.

Junges, J.R. 2004. Uma leitura crítica da situaçáo do idoso no atual contexto sociocultural. Estudos Interdisciplinares sobre o Envelhecimento, 6:123-44.

Lima-Costa, M.F.; Facchini, L.A.; Matos, D.L.; James, M. 2012. Mudanças em dez anos das desigualdades em saúde dos idosos brasileiros (1998-2008). Revista de Saúde Pública, 46:100-107.

Lima-Costa, M.F.; Matos, D.L.; Camargos, V.P.; James, M. 2011. Tendências em dez anos das condiçôes de saúde de idosos brasileiros: evidências da Pesquisa Nacional por Amostra de Domicílios (1998, 2003, 2008). Ciência e Saúde Coletiva, 16:3689-3696.
Lucena, F.C. 2008. A mistura das "raças": o caso brasileiro. Revista Ágata, 3:47-64.

Maio, C.M.; Monteiro, S.; Chor, D.; Faerstein, E.; Claudia, S.L. 2005. Cor/raça no estudo Pró-saúde: resultados comparativos de dois métodos de autoclassificação no Rio de Janeiro, Brasil. Cadernos de Saúde Pública, 21:171-180.

Malta, D.C.; Oliveira, M.R.; Moura, E.C.; Silva, S.A.; Zouain, C.S.; Santos, F.P. et al. 2011. Fatores de risco e proteçâo para doenças crônicas não transmissíveis entre beneficiários da saúde suplementar: resultados do inquérito telefônico Vigitel, Brasil, 2008. Ciência e Saúde Coletiva, 16:2011-2022.

Malta, D.C.; Iser, B.P.M.; Sá, N.N.B.; Yokoba, R.T.C.; Moura, L.; Claro, R.M. et al. 2013. Tendências temporais no consumo de tabaco nas capitais brasileiras, segundo dados do VIGITEL, 2006 a 2011. Cadernos de Saúde Pública, 29:812-822.

Neri, M.C.; Soares, W.L. 2007. Estimando o impacto da renda na saúde através de programas de transferência de renda aos idosos de baixa renda no Brasil. Cadernos de Saúde Pública, 23:1845-1856.

Oliveira, B.L.C.A. 2013. Desigualdades raciais na saúde de idosos brasileiros: um estudo baseado na Pesquisa Nacional por Amostra de Domicílios (2008). Dissertação de Mestrado, Universidade Federal do Maranhão, São Luís, Maranhão. 93p.

Oliveira, B.L.C.A.; Silva, A.M.; Baima, V.J.D.; Barros, M.M.P.; Cruz, M.S.B.V.; Cunha, C.L.F. 2010. Situação social e de saúde da população idosa de uma comunidade de São Luís-MA. Revista de Pesquisa em Saúde, 11:25-29.

Oliveira, E.X.G.; Pinheiro, R.S.; Melo, E.C.P.; Carvalho, M.S. 2011. Condicionantes socioeconômicos e geográficos do acesso à mamografia no Brasil, 2003-2008. Ciência e Saúde Coletiva, 16:3649-3664.

Programa das Naçóes Unidas para o Desenvolvimento. 2013. Atlas de desenvolvimento humano: índice de desenvolvimento humano no Brasil 2013. Accessed on 15/08/2013. Available at: http:// atlasbrasil.org.br/2013/download

Rebouças, M.; Gomes, M.M.F.; Barros, M.G.P.; Vaz, F.; Pereira, MG.; Ramos, LR. 2011. Diferença entre perfis de brasileiros idosos no início dos anos 2000. Belo Horizonte, UFMG, 20p.

Rebouças, M.; Pereira, M.G. 2008. Indicadores de saúde para idosos: comparação entre o Brasil e os Estados Unidos. Revista Panamericana de Salud Pública, 23:237-246.

Silva, P.L.N.; Pessoa, D.G.C.; Lila, M.F. 2002. Análise estatística de dados da PNAD: incorporando a estrutura do plano amostral. Ciência e Saúde Coletiva, 7:659-670.

Travassos, C.; Williams, D.R. 2004. The concept and measurement of race and their relationship to public health: a review focused on Brazil and the United States. Cadernos de Saúde Pública, 20:660-678.

Viacava, F.; Souza-Junior, P.R.B.; Moreira, R.S. 2009. Estimativas da cobertura de mamografia segundo inquéritos de saúde no Brasil. Revista de Saúde Pública, 43:117-25. 
Zaitune, M.P.A.; Barros, M.B.A.; César, C.L.G.; Carandina, L.; Goldbaum M.; Alves, M.C.G.P. 2010. Fatores associados à prática de atividade física global e de lazer em idosos: Inquérito de Saúde no Estado de São Paulo (ISA-SP), Brasil. Cadernos de Saúde Pública, 26:1606-1618.

Zaitune, M.P.A.; Barros, M.B.A.; Lima, M.G.; César, C.L.G.; Carandina, L.; Goldbaum, M.; et al. 2012. Fatores associados ao tabagismo em idosos: Inquérito de Saúde no Estado de São Paulo (ISA-SP). Cadernos de Saúde Pública, 28:583-595.

Recebido em 01/09/2013

Aceito em 04/11/2013 